\title{
The Impact of Selected Contextual Factors on the Teachers' Perception of the Achievement of Goals and Objectives in Teaching Technical Culture
}

\author{
Damir Purković ${ }^{1}$ and Igor Jelaska ${ }^{2}$ \\ 'Department of Polytechnics, Faculty of Humanities and Social Sciences, \\ University of Rijeka \\ ${ }^{2}$ Faculty of Kinesiology, University of Split
}

\section{Abstract}

The aim of this research was to identify and explain the impact of selected contextual factors on the teachers' perception of the achievement of goals and objectives in teaching technical culture in Croatian elementary school, as basic technical education teaching. In accordance with the research goal, a representative sample of teachers of Technical Education was used $(N=382)$, and data were collected in a questionnaire specially developed for this study. In this connection multiple regression analysis with forward algorithm selection of variables in the model was used, with the teachers' perception of the achievement of teaching goals and objectives as the criterion variable, and a set of predictors consisted of selected curricular, extracurricular and empirical teacher's contextual factors of education. Although the result has shown a relatively low correlation between the criterion variable and a set of predictors, it is statistically significant $(p<0.000)$. Research results unambiguously identify school equipment consisting of necessary tools and machinery as an important factor of influence on the teachers' perception of the achievement of goals and objectives of teaching technical culture. In the end, this factor can be considered extremely important for successful teaching of technical 
culture, and its meaning must be taken into account in future studies on the impact of context on the effectiveness of technical education.

Key words: contextual factors; teachers' perception; teaching goal; teaching objective; technical culture; technical education.

\section{Introduction}

Teaching technical culture, as every technical and technology education, is specific in terms of material and organization. In terms of material, it demands an exemplary material-technical basis for teaching, and in organizational terms it requires necessary cooperation with the external world, that is, with various economic and technicalmanufacturing subjects. Therefore, high-quality material-technical teaching conditions and a constructive link with the economy should be very important for its successful realization. Regarding the age of elementary school pupils, an active cooperation between parents and school can also have a great influence on teaching, especially if parents support such cooperation (Pahić et al., 2010). It is important to emphasize that, on the basis of insight into particular considerations of the teaching context (Teddlie, 1991), those factors which directly or indirectly influence the teaching and are not a result exclusively of immediate interaction and personality of teachers and students can be regarded as contextual and environmental teaching factors. Various research studies on upbringing and education, aside from the teaching field, have shown that, in addition to teachers, various elements in the teaching and non-teaching environment can have a crucial influence on the assessment of teaching goals and objectives, as output values of that process (Sremić \& Rijavec, 2010; Borić, Škugor, \& Perković, 2010). Furthermore, the research points to the utmost importance of contextual factors which can influence the effectiveness of the teaching process and usually represent a framework for research: students' socioeconomic environment, the educational level of school, the urban level of environment, school ownership and school management system, teachers' experience, the complexity of teaching techniques and technologies, external pressures to improve the teaching efficiency, and the participation of schools in various projects to improve teaching (Bosker \& Wistziers, 1997; Tedlie, 1991). Taking into account particularities of each factor, the above mentioned factors do not necessarily have the same influence on the teaching process in every educational system and in every educational field.

The goals and objectives of the subject Technical Culture, as well as the guidelines for their achievement have been realized in the current curriculum (Teaching Programmes for Compulsory Education, 2006), while the target competences have been defined by the National Curriculum Framework (NOK) for compulsory general education (National Curriculum Framework, 2011). However, key competences in NOK were taken over from a European document concerning key competences for lifelong learning (2006/962/EC). According to these documents, the goals and objectives of teaching technical culture can be reduced to several essential components: developing 
creative technical-technological thinking, creating active and entrepreneurial awareness, using technical and IT equipment and systems from the environment, developing basic technical skills, and orientation to the technical and productive field in the future professional work. The implementation of the programme should be carried out mainly using the following working methods: students' work in technical experiments, practice which includes making simple technical products and carrying out project construction objectives (Teaching Programmes for Compulsory Education, 2006). These components clearly indicate the complexity of the learning process which should be brought about in order to actualize already mentioned teaching goals and objectives, that is, to enable students to achieve the desired competences. Therefore, checking their achievement can become a demanding process which often cannot be checked through the existing evaluation mechanisms. Namely, by evaluating the teaching process it is possible to check the level of achievement concerning the specific learning outcomes which usually relate to the knowledge and comprehension of the matter, while the variables, essential for coping with the working process and life, are most often not checked (Matijević, 2005). Using this kind of evaluation it is partly possible to evaluate students' independence and responsibility by checking some abilities and skills. Nevertheless, even after such an extensive evaluation, its complete validity could be disputable. The reason for this lies in the educational dimension of teaching whose purposefulness should be searched for in the development of complex ethical and moral competences, because knowledge by itself does not humanize, it informs but does not form, and the basic sense and purpose of education is to form people (Vukasović, 2010). The educational component of teaching technical education is manifested through the development of functional education, that is, through the development of value relationships towards work and possible affirmation of students in their further professional technical education and work. Taking into consideration that the essential component of education is the experience of values, that is, conveying, transplanting and proclaiming values (Vukasović, 1987), it is not possible to evaluate these competences unilaterally. Teachers, as direct participants of the teaching process, are the only and often most competent evaluators of the efficiency in teaching technical culture, and thereby of the level of achievement of goals and objectives of that teaching. Consequently, the teachers' perception of the achievement of teaching goals and objectives can be considered the most acceptable indicator of that achievement.

\section{The Problem of Validity of the Teachers' Perception Related to Teaching Effectiveness}

The influence of the teachers' perception of the accomplishment of teaching goals and objectives on the effect of that teaching is based on the concept of self-efficacy in the socio-cognitive theory (Bandura, 1986). In fact, this specific situational structure claims that the perception of teaching, if positive, can have a positive effect on the 
accomplishments. Teachers with a strong sense for the effectiveness of teaching are more tolerant of students' errors; they make efforts to secure students' success and are more willing to take risks and apply new teaching strategies because they are less afraid of failure (Knoblauh \& Woolfolk Hoy, 2008). Research on the impact of the narrower and wider context on teaching and teachers' views, as well as the impact of these views on real teaching effectiveness have shown that the context can substantially affect the teachers' perception of the effectiveness and the teaching effectiveness itself (Bandura, 1997; Goddard \& Goddard, 2001). Nevertheless, the context is not the field in which the effectiveness of teachers should be primarily researched (Labone, 2004).

The teacher, as the most competent internal evaluator of teaching, is able, with a high level of validity and reliability, to evaluate the teaching accomplishments and the achievement of teaching goals and objectives as a whole (Ashton \& Webb, 1986). Anyway, the teachers' perception of the achievement of teaching goals and objectives should be considered exclusively as their perception of that achievement and not as a real and final value of the achievement of teaching goals and objectives. In this respect, the teachers' perception can, at the same time, represent a certain limitation in the analysis of evaluation of the achievement of teaching goals and objectives.

The above-mentioned limitation does not diminish the value of the teachers' perception of the achievement of teaching goals and objectives as a real indicator of that achievement, and also as a result of effects of various factors on that perception. In that sense, the relation between the teachers' perception and the teaching effectiveness can be seen as: (i) the influence of the teachers' perception on the teaching process; (ii) the influence of various contextual (environmental) factors of teaching on that perception and (iii) the influence of contextual factors on the teaching process. The teachers' perception, besides being essential as an indicator of teaching effectiveness, is also essential regarding the satisfaction with such teaching, which can have positive effects on the teaching and the students as the main participants of that process. Therefore, the elements which are directly connected and directly affect the teachers' perception can also have a direct influence on the overall quality of teaching. Along with all that, some specific contextual factors in teaching technical culture, linked with the teachers' perception of the achievement of teaching goals and objectives, can become significant for planning, preparation and implementation of teaching.

\section{Research Aims}

This research has been primarily focused on the identification and explanation of the influence of those measurable contextual (environmental) factors in teaching technical culture which can predict teachers' perception of the achievement of teaching goals and objectives, and thus can significantly affect the quality of teaching.

The secondary research goal refers to the teachers' evaluation of the school equipment consisting of material-technical tools needed for teaching technical culture, and to data concerning teachers' work experience. This part of the research goal has 
been conducted in order to carry out the primary goal, as well as to analyse particular elements of material-technical basis for teaching technical culture.

\section{Methods}

With regard to a large number of possible contextual factors which can affect the achievement of teaching goals and objectives, and the problems in the realization of such research in given circumstances, this research was carried out in two phases. In the first phase a special short questionnaire was designed, and the initial validation of the questionnaire was conducted on a limited sample of technical education teachers $(\mathrm{N}=26)$. The validation was conducted on the basis of feedback - teachers' suggestions with the purpose of constructing items and facilitating the operationalization of the research. As a result of the initial validation another short questionnaire was designed and used in the second phase of the research. The questionnaire comprises, along with the teachers' perception of the achievement of goals and objectives in teaching technical culture, the variables relating the teachers' work experience, the school's material-technical equipment for teaching technical culture and the relation between parents and economic subjects on one side and the school on the other. Except for numerical variables relating to teachers' work experience, a four-point scale estimation was used for predictor variables: 1-poor, 2-satisfactory, 3-good, 4-excellent. The fourpoint scale estimation was also used for the teachers' perception of achievement of goals and tasks of teaching: 1-not achieved, 2-partially achieved, 3-mostly achieved, 4 -entirely achieved. These scales were chosen as optimal, based on the teachers' suggestion during the first phase of the research.

In the second research phase, a sample of 382 teachers of technical culture was administered the above-mentioned questionnaire, and that sample represents a proportional stratified sample of technical culture teachers in the Republic of Croatia. The questionnaire was posted online, on the website for poll questionnaires of the Department of Polytechnics, Faculty of Humanities and Social Sciences in Rijeka. The access to the questionnaire was limited for security reasons using a single teacher's personal access key (token). Authentication of received data was performed through communication interface, and the answers about questionnaire ambiguities were given to teachers. In the course of research, the variable related to the years of service in technology and production was excluded because a great number of teachers did not answer that question.

Parameters of descriptive statistics were calculated for all variables: mean (M), standard deviation (SD), coefficient of variation (CV), asymmetry (SKEW) and curvature (KURT) of the distribution of the results.

In further statistical processing, multiple regression analysis with forward algorithm selection of variables in the model was used, and in the process, the evaluation of the achievement of teaching goals and objectives (ATGO) was taken as the criterion variable, while the following were the predictor variables: teaching years (TY), work 
experience in extracurricular activities (WEEA), the evaluation of cooperation with economic agents (EVES), the evaluation of cooperation with parents (EVCP), the evaluation of equipment including tools and machines (EVTM), the evaluation of equipment consisting of instruments (EVCI), the evaluation of equipment including computers, interfaces and software (EVCS) and the evaluation of equipment including teaching tools and their condition (EVTT). The coefficient of multiple correlations and the coefficient of multiple determinations were calculated, as well as the parameters $\mathrm{b}$ and beta and corresponding significance. All data were computer-processed using the statistical program Statistica 8.0.

\section{Results}

All variables, including the criterion variable were analysed using descriptive statistics, primarily due to the realization of the secondary goals of research related to the analysis of some elements of the material-technical base of teaching technical culture, but also in order to identify the structure of the respondents. The characteristics of distribution of certain variables were also identified in order to select an optimal methodology for determining those predictors that can directly affect teachers' perception of the achievement of teaching goals and objectives.

Table 1

Parameters of descriptive statistics: mean (M), standard deviation (SD), coefficient of variation (CV), skewness (SKEW), kurtosis (KURT)

\begin{tabular}{lrrrrr}
\hline Monitored variables & M & SD & CV\% & SKEW & KURT \\
\hline $\begin{array}{l}\text { Perception of achievement of teaching goals and objectives } \\
\text { (ATGO) }\end{array}$ & 3.16 & 0.60 & 18.99 & -0.15 & -0.01 \\
Work experience in teaching (TY) & 16.89 & 11.73 & 69.40 & 0.41 & -0.99 \\
Work experience in extracurricular activities (WEEA) & 10.75 & 10.83 & 100.70 & 1.01 & 0.07 \\
Evaluation of cooperation with economic agents (EVES) & 1.71 & 0.82 & 47.90 & 0.76 & -0.58 \\
Evaluation of cooperation with parents (EVCP) & 2.46 & 0.71 & 29.00 & -0.04 & -0.26 \\
Evaluation of equipment including tools and machines (EVTM) & 1.71 & 0.77 & 44.80 & 0.66 & -0.65 \\
Evaluation of equipment consisting of instruments (EVCI) & 1.57 & 0.69 & 43.80 & 0.85 & -0.28 \\
$\begin{array}{l}\text { Evaluation of equipment including computers, interfaces and } \\
\text { software (EVCS) }\end{array}$ & 2.41 & 0.93 & 38.50 & -0.08 & -0.90 \\
$\begin{array}{l}\text { Evaluation of equipment including teaching tools and their } \\
\text { condition (EVTT) }\end{array}$ & 1.90 & 0.78 & 40.90 & 0.31 & -0.90
\end{tabular}

The values of descriptive statistic parameters selected from predictor variables (see Table 1) evidently show the empirical structure of examinees and their evaluation of individual selected contextual teaching elements. Examinees, although, on average, having a long work experience in teaching $(>16$ years) and non-teaching activities $(>10$ years), with respect to the high dispersion of those results (CV=69.40\%), represent groups of technical culture teachers of all ages and experience. This fact is of crucial importance in view of the consequently higher level of representativeness of the results of this research. Furthermore, when it comes to the evaluation of cooperation between the school and selected external elements, it is noticeable that the cooperation 
with parents received a higher rating than the cooperation between schools and economic agents. Also, regarding the previous rating scale, the average evaluation of cooperation between schools and economy is below satisfactory level, while the average evaluation of cooperation between schools and parents is still above that level. Table 1 shows that, when the evaluation of the equipment including various kinds of material-technical basis of teaching technical culture is concerned, only the equipment with computers, interfaces and software (EVCS) was rated above the satisfactory level (2.41), while other categories were rated below that level. Data from the table related to the asymmetry of distribution of particular variables indicate that only the data concerning the teachers' experience in extracurricular activities (WEEA) are asymmetrically distributed (SKEW=1.01). Data related to the curvature of distribution of particular predictor variables also indicate that only the variable concerning teachers' experience in extracurricular activities (WEEA) has almost zero kurtosis value (KURT $=0.07$ ), while other variables have a negative kurtosis value. The above-mentioned results point to the fact that there are great differences between the teachers related to such an experience. This fact is clearly seen from the coefficient of variation which is definitely the highest for that variable (100.70\%). In this connection, it is necessary to emphasize that the data about the perception of the achievement of goals and objectives in teaching technical culture (ATGO) and the evaluation of schools' cooperation with parents (EVCP) vary, and their coefficient of variation is $18.99 \%$, that is, $29.00 \%$. In addition, by using the Kolmogorov-Smirnov test, it was observed that some variables slightly vary from normal distribution. That is probably the result of hypersensitivity of the test to relatively large samples, as in the case of this research.

Table 2

Results of regression analysis related to the criterion variable of perception of the achievement of teaching goals and objectives (ATGO) with forward algorithm selection of variables included in the model: beta coefficient ( $\beta$ ), $b$ coefficient (b), coefficient of multiple correlation ( $R$ ), coefficient of determination $\left(R^{2}\right)$ and corresponding significance $(p)$.

\begin{tabular}{lccc} 
& $\beta$ & $b$ & $p$ \\
\cline { 2 - 4 } Intercept & & 2.66 & 0.00 \\
Evaluation of equipment including tools and machines (EVTM) & 0.20 & 0.16 & 0.00 \\
Evaluation of cooperation with economic agents (EVES) & 0.09 & 0.07 & 0.07 \\
Evaluation of equipment including teaching tools and their condition (EVTT) & 0.08 & 0.06 & 0.16 \\
$\mathrm{R}$ & 0.28 & & 0.00 \\
$\mathrm{R}^{2}$ & 0.08 & &
\end{tabular}

However, from the analysis of descriptive statistics it is not possible to determine the relationship between predictor variables and teachers' perceptions of the achievement of teaching goals and objectives. In accordance with the above-mentioned, it is appropriate to use multiple regression analysis as a methodological tool in data processing.

By conducted multiple regression analysis (see Table 2) a model with three predictor variables which most significantly define the criterion variable was obtained. These 
variables are: the evaluation of equipment including tools and machines (EVTM), the evaluation of cooperation with economy (EVES) and the evaluation of equipment including teaching tools and their condition (EVTT).

Multiple correlations of these variables towards the criterion variable (ATGO) are relatively low $\mathrm{R}=0.28$. The beta coefficient from Table 2 indicates that the variable of the evaluation of equipment including tools and machines (EVTM) mostly defines the criterion variable $(\beta=0.20)$, at the significance level $p=0.00$. This is the most important finding in this research, which suggests that the use of equipment including tools and machines in teaching technical culture can significantly influence, or predict, teachers' perception of teaching success. Taking into account all the limitations of the teachers' perception of teaching success, there is no doubt that the equipment including tools and machines used in teaching technical culture can significantly affect the quality of teaching in general. With regard to the primary purpose of tools and machinery, it is significant that the teachers largely base their perception of the achievement of teaching goals and objectives in teaching technical culture on practical activities of students in the classroom.

Variables of the evaluation of schools' cooperation with economy (EVES) and the evaluation of equipment including teaching tools and their condition (EVTT) less significantly define the criterion variable $(\beta=0.09 / 0.08)$ with the significance level $\mathrm{p}>0.05$. Although, because of such a small significance, these contextual factors cannot be considered real predictors of the teachers' perception of the teaching goals and objectives, their appearance in this model is indicative. Schools' cooperation with economy (EVES), as a predictor of the teachers' perception of teaching, has not been expected in this model, which is important for the research. Irrespective of the small impact on the criterion variable, the finding of this variable indicates that the teaching of technical culture needs to rely on a broader context, with which it should be linked because of its working-social and professional functions (Milat, 1996). The Influence of the variable of equipment including teaching tools and their condition (EVTT) on the criterion variable, and thus the share of this variable in the resulting model, is expected, but it is unexpectedly small.

The absence of other predictor variables from this model is more significant because it clearly shows that many of the contextual factors, which were considered important for the teachers' perception of teaching, in fact, do not significantly affect this perception.

\section{Discussion}

The separated model clearly indicates that, aside from the low $\beta$ coefficient and the correlation of the model with the criterion variable $(\mathrm{R}=0.28)$, the evaluation of equipment including tools and machines (EVTM), in teaching technical education, was identified as a significant predictor which displays the importance of this research. This significance is important to such a degree because contextual factors are not a basis for the evaluation of the teaching process and teachers. 
Relating to the sample size, and the variety in terms of age, education and urban structure of teachers, and their varied work experience (see Table 1) the research established that the evaluation of particular contextual factors can be considered as a real indicator of the actual state in the Republic of Croatia. According to those indicators, the worst mark was given to school equipment involving instruments (1.54) needed for technical experiments, which are, in teaching technical culture, supposed to be a crucial component of the working method scheduled in the school curriculum (Teaching Programmes for Compulsory Education, 2006). School equipment including teaching tools and machines and the cooperation between schools and economy was also rated very low. The insufficient school equipment including tools and machines undoubtedly determines the realisation of the second important component of the working method assigned by the school curriculum, which is the production of simple technical products. In view of the fact that the evaluation of the state and level of teaching tools equipment is on the verge of a positive mark (1.90), it is questionable whether the implementation of the third component of the working method, essential for the realisation of the programme related to project construction tasks, is possible. Such grades certainly do not guarantee a successful realization of the technical culture curriculum, that is, the achievement of teaching goals and objectives. Nevertheless, the imperfection of poorly graded factors is by no means something that could not be successfully influenced in order to improve these factors. Among all the contextual factors, only the evaluation of IT equipment including computers, interfaces and software (2.41) and the evaluation of cooperation between schools and parents (2.46) were positively graded. It is important to point out that the evaluation of computers and IT equipment and their condition is the result of a long lasting and permanent investment of the whole community and competent institutions into school computerisation, but obviously, this equipment itself is not associated with the teachers' perception of the achievement of goals and objectives in teaching technical culture, therefore, it is probably not associated with the efficiency of teaching technical culture as well. A positive evaluation of the cooperation between schools and parents will certainly have a positive impact on teaching technical culture, but there is no significant evidence related to the impact of this evaluation on the teachers' perception of the achievement of teaching goals and objectives.

The results of the multiple regression analysis (see Table 2) obviously display the structure and significance of the influence of particular contextual factors on the teachers' perception of the achievement of goals and objectives in teaching technical culture. Although the value of multiple correlation of separated model is not high $(\mathrm{R}=0.28)$, separated predictor variables can still be considered indicative for that perception. In this context, the most important is the variable of the evaluation of equipment including tools and machines whose significance at the level $\mathrm{p}=0.00$ strongly indicates that tools and machines, as some of the most important material prerequisites in teaching technical education, are essential elements of the teachers' 
perception of effectiveness in teaching technical culture. The model also displays the importance of the evaluation of cooperation between schools and economy (EVES) which, at the verge of significance $(\mathrm{p}=0.07)$, participates in the teachers' perception. All three variables included in the regression model reveal more about the fact that some monitored variables are not an integrated part of that model than about their significance. In this connection it is noticeable that the teachers' perception is more determined by the evaluation of cooperation between schools and economy than by some, seemingly more important, factors such as the evaluation of cooperation between schools and parents or teachers' work experience. As for the last variable of the model, with very low participation ( $\mathrm{p}=0.16)$, its correlation with the teachers' perception was expected in view of the fact that teaching tools are an essential component of the material-technical basis of teaching technical culture. It is not surprising that the evaluation of the equipment including computers, interfaces and software is not connected with the teachers' perception. This result is probably the consequence of the intense presence of computers and computer equipment over the last two decades, but also the consequence of inadequacy of equipment as a fundamental material basis of technical education. What is more, the fact that the evaluation of equipment including instruments is not connected with the teachers' perception is also not surprising because, regarding the lowest average rating (1.57), it is obvious that technical experiments in teaching technical culture are utterly neglected and that has an impact on the teachers' perception of the achievement of teaching goals and objectives.

Although the research undoubtedly indicates the significance of particular contextual factors in teaching technical culture, it is necessary to observe its possible limitations as well. Apart from the teachers' subjective evaluation of the achievement of teaching goals and objectives, which can be a limiting factor in this research, the lack of data, relevant to the teaching context, can also diminish the research results. Namely, a great number of contextual factors like urbanity of the place in which teaching classes are held, the living standard of students' families, the economic development of the region, economic structure, school management and administration, and cultural characteristics of social environment can also have an impact on the teaching and the teachers' perception of achievements in this teaching. Since it is difficult to have a direct influence on these factors in the actual organization of the teaching and since it requires a long and demanding process to research them, they are omitted from this research. However, their omission is consequently an essential limitation, as their eventual impact on the teachers' perception of the achievement of goals and objectives in teaching technical culture cannot be clearly anticipated.

\section{Conclusions}

Operationalization of the primary research objective has identified and explained measurable contextual factors which were supposed to be able to have an impact 
on the teachers' perception of the level of achievement of goals and objectives in teaching technical culture. In the context of that goal, the research has identified an important contextual factor in teaching technical culture, essential for the achievement of teaching goals and objectives, and that is the equipment concerning tools and machines necessary for the teaching process. At the same time, the research has also shown the condition of essential contextual factors, that is, the material-technical basis needed in teaching technical culture, such as: tools, machines, instruments and teaching tools. Considering that these are factors that can be improved with a minimal involvement of appropriate resources, this markedly low rating of the state can be considered as an acute problem in teaching technical culture.

Furthermore, the research results of the teachers' perception of the achievement of teaching goals and objectives point to validity of many empirical indicators which suggest the importance of the context in technical education. The conducted research indicatively suggests that the material-technical environment in which technical culture is taught has an important effect on the teachers' perception of that teaching. The results display a noticeable importance of the internal (school) environment, but the importance of the external (technical-productive) environment for the teachers' perception is also indicative.

All of the above-mentioned indicators can only mean that a good material-technical basis for teaching and a cooperative technical-productive environment are necessary prerequisites for a better rating of the teachers' perception of the achievement of goals and objectives in teaching technical culture. Further research in the area of technical education should certainly take into consideration equipment including tools and machines, as well as the relationship between school and technical-productive environment as essential predictors of the effectiveness of such education.

\section{References}

Ashton, P. T., \& Webb, R. B. (1986). Making a difference: Teachers' sense of efficacy and student achievement, New York: Longman.

Bandura, A. (1986). Social foundation of thought and action: A social cognitive theory, Englewood Cliffs, NJ: Prentice-Hall.

Bandura, A. (1997). Self efficacy: The exercise of control, New York: Freeman.

Borić, E., Škugor A., \& Perković, I. (2010). Teachers' assessments toward out-of-classroom research teaching in natural and social sciences. Educational Sciences, 12(2), 361-371.

Bosker, R., Wistziers, B. (1997). A meta-analysis on the effects of presumed school effectiveness enhancing factors /online/. Retrieved on 23rd December 2011 from http://www. highreliability.co.uk.

Goddard, R.D., \& Goddard, Y.L. (2001). A multilevel analysis of the relationship between teacher and collective efficacy in urban schools. Teaching and Teacher Education, 17 (2001), 807-818. http://dx.doi.org/10.1016/S0742-051X(01)00032-4 
Knoblauh, D., \& Woolfolk Hoy, A. (2008). “Maybe I can teach those kids." The influence of contextual factors on student teacher's efficacy beliefs. Teaching and Teacher Education, 24, 166-179. http://dx.doi.org/10.1016/j.tate.2007.05.005

Labone, E. (2004). Teacher efficacy: maturing the construct through research in alternative paradigms. Teaching and Teacher Education, 20 (2004), 341-359. http://dx.doi. org/10.1016/j.tate.2004.02.013

Matijević, M. (2005). Evaluation in education. Pedagogijska istraživanja, 2, 279-298.

Milat, J. (1996). Technical training is an important determinant of the system of education, Društvena istraživanja, 5(1), 109-128.

MSES/MZOŠ, (2006). Teaching Programmes for Compulsory Education (pp. 304-309) /online/. Retrieved on 23rd November 2011 from http://public.mzos.hr/fgs.axd?id=14181.

MSES/MZOŠ, (2011). National Curriculum Framework (pp. 160-170) /online/. Retrieved on 23rd November 2011 from http://public.mzos.hr/fgs.axd?id=18247.

Pahić, T., Miljević-Riđički, R., \& Vizek Vidović, V. (2010). Parental involvement in school life: perception of regular parents and representatives. Educational Sciences, 12(2), 329-346.

European Commission (2006). Recommendation 2006/962/EC of the European Parliament and of the Council of 18 December 2006 on key competences for lifelong learning /online/. Retrieved on $14^{\text {th }}$ August 2012 from http://eur-lex.europa.eu/LexUriServ/LexUriServ. do?uri=OJ: L:2006:394:0010:0018:en:PDF.

Sremić, I., \& Rijavec, M. (2010). Relationship between perception of mothers and fathers parental behaviour and academic achievement. Educational Sciences, 12(2), 347-360.

Teddlie, C. (1991). The Use of Context Variables in School Effects Research /online/. Retrieved on $12^{\text {th }}$ September 2012 from http://www.highreliabilityschools.co.uk/_resources/files/ downloads/school-effectiveness/ct1991a.pdf.

Vukasović, A. (1987). Contributions towards consideration and scientific insight into of the phenomenon of upbringing. Prilozi za istraživanje hrvatske filozofske baštine, 13, 163-180.

Vukasović, A. (2010). Educational transformation in a teleological and axiological context. Educational Sciences, 12, (1), 97-117.

\section{Damir Purković}

Faculty of Humanities and Social Sciences, University of Rijeka Sveučilišna avenija 4, 51000 Rijeka, Croatia

damir@ffri.hr

\section{Igor Jelaska}

Faculty of Kinesiology, University of Split

Teslina 6, 21000 Split, Croatia

jelaska@kifst.hr 


\section{Utjecaj odabranih kontekstualnih čimbenika na nastavnikovu percepciju ostvarenosti ciljeva i zadaća nastave tehničke kulture}

\section{Sažetak}

Cilj istraživanja bio je utvrditi i objasniti utjecaj određenih kontekstualnih čimbenika na nastavnikovu percepciju ostvarenosti ciljeva i zadaća u nastavi Tehničke kulture u osnovnoj školi, kao nastavi temeljne edukacije tehnike. U skladu s ciljem istraživanja upotrijebljen je reprezentativni uzorak učitelja Tehničke kulture $(N=382)$, a podaci su prikupljeni anketnim upitnikom, posebno izradenim za ovo istraživanje. Provedena je višestruka regresijska analiza s forward algoritmom selekcije varijabli u model, pri čemu je kriterijska varijabla bila nastavnikova percepcija ostvarenosti ciljeva i zadaća nastave, a skup prediktora činili su odabrani školski, izvanškolski i iskustveni nastavnikovi kontekstualni čimbenici nastave. Iako je dobivena relativno mala povezanost kriterijske varijable i skupa prediktora, ona je statistički značajna ( $p<0.000)$. Rezultati istraživanja nedvosmisleno identificiraju opremljenost škole neophodnim alatima i strojevima kao važnim čimbenikom utjecaja na nastavnikovu percepciju ostvarenosti ciljeva i zadaća nastave Tehničke kulture. Taj čimbenik može se smatrati izrazito važnim za uspješnu nastavu Tehničke kulture, pa njegovo značenje nužno treba uzeti u obzir pri budućim istraživanjima utjecaja konteksta na učinkovitost edukacije tehnike.

Ključne riječi: ciljevi nastave; edukacija tehnike; kontekstualni čimbenici; nastavnikova percepcija; tehnička kultura; zadaće nastave.

\section{Uvod}

Nastava Tehničke kulture, kao i svaka edukacija tehnike, specifična je u materijalnom i organizacijskom smislu. U materijalnom smislu zahtijeva egzemplarnu materijalnotehničku podlogu nastave, a u organizacijskom smislu neophodnu suradnju s vanjskim svijetom, odnosno s različitim privrednim i tehničko-proizvodnim subjektima. Zbog toga bi kvalitetni materijalno-tehnički uvjeti nastave i konstruktivan odnos s gospodarstvom trebao biti od iznimne važnosti za njezinu uspješnu realizaciju. 
S obzirom na osnovnoškolsku dob učenika aktivna suradnja roditelja i škole može također znatno utjecati na tu nastavu, osobito ako roditelji takvu suradnju i podupiru (Pahić i sur., 2010).Važno je istaknuti da se, na temelju uvida u pojedina razmatranja konteksta nastave (Tedlie, 1991), oni čimbenici koji izravno ili neizravno utječu na nastavu, a nisu produkt isključivo neposredne interakcije i osobnosti nastavnika i učenika mogu smatrati kontekstualnim ili okolinskim čimbenicima nastave. Različita istraživanja odgoja i obrazovanja, neovisno o nastavnom području, pokazala su kako, osim nastavnika, razni elementi školskog i izvanškolskog okruženja mogu presudno utjecati na ostvarenost ciljeva i zadaća nastave, kao izlaznih vrijednosti toga procesa (Sremić i Rijavec, 2010; Borić, Škugor, Perković, 2010). Nadalje, istraživanja ukazuju na to da su najvažniji kontekstualni čimbenici koji mogu utjecati na učinkovitost nastavnog procesa i koji najčešće predstavljaju okvir za istraživanje: socioekonomsko okruženje učenika, obrazovna razina škole, urbana razina okruženja, vlasništvo i sustav upravljanja školom, iskustvo nastavnika, složenost nastavne tehnike i tehnologije, vanjski pritisci za poboljšanjima učinka nastave i sudjelovanje škole u različitima projektima poboljšanja nastave (Bosker i Wistziers, 1997; Tedlie, 1991). S obzirom na posebnosti svakoga pojedinog čimbenika navedeni ne moraju nužno na isti način utjecati na nastavu u svakom obrazovnom sustavu, kao ni na svako nastavno područje.

Ciljevi i zadaće nastavnog predmeta Tehnička kultura, kao i smjernice za njihovo ostvarivanje, konkretizirane su važećim nastavnim planom i programom (Nastavni plan i program za osnovnu školu, 2006), dok su ciljane kompetencije određene Nacionalnim i okvirnim kurikulumom (NOK) za opće obvezno obrazovanje (Nacionalni okvirni kurikulum za predškolski odgoj te opće obvezno i srednjoškolsko obrazovanje, 2011). Ključne kompetencije iz NOK-a preuzete su iz europskog dokumenta o ključnim kompetencijama za cjeloživotno učenje (2006/962/EC). Prema tim dokumentima ciljevi i zadaće nastave tehničke kulture mogu se svesti na nekoliko bitnih komponenti: razvoj stvaralačkog tehničko-tehnološkog mišljenja, izgradnja djelatne i poduzetničke svijesti, upotreba tehničkih i informatičkih tvorevina i sustava iz okruženja, razvoj temeljnih tehničkih vještina, usmjerenost na tehničko i proizvodno područje u budućem profesionalnom djelovanju. Za realizaciju programa predviđena je uglavnom radna metoda koja podrazumijeva: rad učenika u tehničkom pokusu, vježbe izrade jednostavnih tehničkih tvorevina i rad na projektnim konstrukcijskim zadacima (Nastavni plan i program za osnovnu školu, 2006). Već je iz tih komponenti uočljiva sva kompleksnost nastavnog procesa koji treba provesti kako bi se realizirali navedeni ciljevi i zadaće nastave, odnosno stekle željene kompetencije. Stoga provjera njihove ostvarenosti može predstavljati vrlo zahtjevan proces koji često nije moguće provjeriti postojećim evaluacijskim mehanizmima. Naime, evaluacijom je u nastavi moguće provjeriti razinu ostvarenosti određenih ishoda učenja koji se najčešće odnose na znanje i razumijevanje gradiva, a varijable bitne za snalaženje u radnom procesu i životu najčešće se ne procjenjuju (Matijević, 2005). Kroz takvu evaluaciju moguće je djelomice vrednovati i samostalnost i odgovornost učenika provjeravanjem 
određenih umijeća i vještina. Ipak, i nakon takve opsežne evaluacije, upitna bi bila njezina potpuna valjanost. Razlog je u odgojnoj dimenziji nastave čiju svrhovitost treba tražiti u razvoju složenih etičkih i moralnih kompetencija, jer znanje samo po sebi ne očovječuje, informira, ali ne formira, a temeljni smisao i svrha odgajanja je ljudsko formiranje (Vukasović, 2010). Odgojna komponenta nastave tehničke kulture dolazi do izražaja kroz razvoj radnog odgoja, odnosno, razvoj vrijednosnih odnosa prema radu, i moguću afirmaciju učenika u daljnjem profesionalnom tehničkom obrazovanju i djelovanju. S obzirom na to da je bitna sastavnica odgoja vrijednosno doživljavanje, odnosno prenošenje, rasađivanje i očitovanje vrednota (Vukasović, 1987), te kompetencije nije moguće jednostrano evaluirati. Jedini i često najkompetentniji evaluatori uspješnosti nastave tehničke kulture, pa time i razine ostvarenosti ciljeva i zadaća te nastave, jesu nastavnici kao njezini izravni sudionici. Posljedica toga je da se nastavnička percepcija ostvarenosti ciljeva i zadaća nastave može smatrati najprihvatljivijim pokazateljem te ostvarenosti.

\section{Problem valjanosti nastavnikove percepcije učinkovitosti nastave}

Utjecaj nastavnikove percepcije ostvarenosti ciljeva i zadaća nastave na učinak te nastave ima temelje u socijalno kognitivnoj teoriji (Bandura, 1986), odnosno pojmu samoučinkovitosti. Taj specifični situacijski konstrukt zapravo govori kako sama percepcija nastave, ako je pozitivna, može pozitivno djelovati na postignuća. Nastavnici s izraženim osjećajem za učinkovitost nastave tolerantniji su prema učeničkim pogreškama, nastoje se izboriti za uspjeh učenika i spremniji su preuzeti rizike primjene novih strategija u nastavi zbog manje izraženog straha od neuspjeha (Knoblauh i Woolfolk Hoy, 2008). Istraživanja utjecaja užeg i šireg konteksta na nastavu i nastavnikova uvjerenja, kao i utjecaja tih uvjerenja na stvarnu učinkovitost nastave pokazala su da kontekst može bitno utjecati na nastavnikovu percepciju učinka i na sam učinak nastave (Bandura, 1997; Goddard i Goddard, 2001). Ipak, kontekst nije područje u kojem bi primarno trebalo istraživati učinkovitost nastavnika (Labone, 2004).

Nastavnik, kao najkompetentniji unutarnji evaluator nastave, može s visokom razinom valjanosti i pouzdanosti procijeniti postignuća u nastavi, kao i ostvarenost ciljeva i zadaća nastave u cjelini (Ashton i Webb, 1986). Ipak, nastavnikovu procjenu ostvarenosti ciljeva i zadaća nastave treba gledati kao njegovu percepciju te ostvarenosti, a ne kao nedvosmislenu, stvarnu i konačnu veličinu ostvarenosti ciljeva i zadaća nastave. U tom smislu nastavnikova percepcija ujedno može predstavljati i određeno ograničenje pri analizi ocjena ostvarenosti ciljeva i zadaća nastave, kao rezultata takve percepcije.

Navedeno ograničenje nikako ne umanjuje vrijednost nastavnikove percepcije ostvarenosti ciljeva i zadaća nastave kao stvarnog pokazatelja te ostvarenosti, ali i kao rezultata djelovanja različitih čimbenika na tu percepciju. U tom smislu odnos nastavnikove percepcije i učinka nastave može se promatrati kao: (i) utjecaj 
nastavnikove percepcije na nastavni proces, (ii) kao utjecaj različitih kontekstualnih (okolinskih) čimbenika nastave na tu percepciju i (iii) kao utjecaj kontekstualnih čimbenika na nastavni proces. Nastavnikova percepcija, osim što je bitna kao pokazatelj učinka nastave, bitna je i iz aspekta zadovoljstva tom nastavom, što može imati pozitivne učinke na nastavu i na učenike kao glavne sudionike tog procesa. Zbog toga elementi koji su izravno povezani i izravno djeluju na nastavnikovu percepciju mogu imati i izravan utjecaj na kakvoću te nastave u cjelini. To određene kontekstualne čimbenike nastave tehničke kulture, koji su povezani s nastavnikovom percepcijom ostvarenosti ciljeva i zadaća nastave, može učiniti značajnima za planiranje, pripremanje i provedbu te nastave.

\section{Cilj istraživanja}

Ovo istraživanje primarno je usmjereno na utvrđivanje i objašnjenje utjecaja onih mjerljivih kontekstualnih (okolinskih) čimbenika nastave Tehničke kulture kojima se može predvidjeti nastavnikova percepcija ostvarenosti ciljeva i zadaća te nastave i tako značajnije utjecati na kakvoću te nastave.

Sekundarni cilj istraživanja odnosi se na nastavnikovu ocjenu opremljenosti škole materijalno-tehničkim sredstvima neophodnim za izvođenje nastave tehničke kulture, ocjenu suradnje s okolinom, kao i na podatke o radnom iskustvu nastavnika. Taj dio cilja istraživanja proveden je s ciljem realizacije primarnog cilja, ali i analize pojedinih elemenata materijalno-tehničke osnovice nastave tehničke kulture.

\section{Metode rada}

S obzirom na velik broj mogućih kontekstualnih čimbenika koji mogu utjecati na ostvarenost ciljeva i zadaća nastave, zatim probleme izvodivosti takvog istraživanja u realnim okolnostima, istraživanje je provedeno u dvije etape. U prvoj etapi sastavljen je poseban kratki upitnik za potrebe istraživanja i provedena je inicijalna validacija toga upitnika na ograničenom uzorku učitelja tehničke kulture $(\mathrm{N}=26)$. Validacija je provedena na temelju povratnih informacija - sugestija učitelja kojima su cilj precizno konstruiranja pojedinih čestica, odnosno prihvatljive operacionalizacije ciljeva istraživanja. Kao posljedica inicijalne validacije oblikovan je vlastiti kratki upitnik koji je upotrijebljen u drugoj etapi istraživanja. Upitnikom su uz nastavnikovu percepciju ostvarenosti ciljeva i zadaća nastave tehničke kulture obuhvaćene varijable povezane s radnim iskustvom nastavnika, stanjem materijalno-tehničke opremljenosti škole za nastavu tehničke kulture, kao i odnosom roditelja i privrednih subjekata prema školi. Osim numeričkih varijabli koje se odnose na radni staž učitelja, za prediktorske varijable upotrijebljena je ljestvica procjene od 4 stupnja: 1-loše; 2-zadovoljavajuće; 3-dobro; 4-izvrsno. Za nastavnikovu percepciju ostvarenosti ciljeva i zadaća nastave upotrijebljena je, također, ljestvica procjene od 4 stupnja: 1-ne ostvaruju se, 2-djelomično se ostvaruju, 3-uglavnom se ostvaruju, 4-ostvaruju se u potpunosti. Takve ljestvice odabrane su kao optimalne na temelju sugestija učitelja tijekom prve etape istraživanja. 
U drugoj etapi istraživanja na uzorku od 382 učitelja tehničke kulture primijenjen je navedeni anketni upitnik, a uzorak predstavlja omjerni stratificirani uzorak učitelja tehničke kulture s područja Republike Hrvatske. Upitnik je postavljen online na anketno web-sjedište Odsjeka za politehniku pri Filozofskom fakultetu u Rijeci. Pristup upitniku bio je sigurnosno ograničen putem jedinstvenog osobnog ključa (tokena) učitelja, dok je preko odgovarajućeg komunikacijskog sučelja provedena dodatna valorizacija unesenih odgovora/ocjena. Komunikacijskim sučeljem obavljena je provjera autentičnosti dobivenih podataka. Učiteljima je odgovarano na postavljena pitanja u pogledu eventualnih nejasnoća u popunjavanju upitnika. Tijekom istraživanja je iz daljnje obrade isključena varijabla koja se odnosi na radni staž u tehnici i proizvodnji zbog velikog broja učitelja koji nisu odgovorili na to pitanje.

Za sve varijable izračunati su parametri deskriptivne statistike: aritmetička sredina (AS), standardna devijacija (SD), koeficijent varijacije (CV), koeficijent asimetričnosti (SKEW) i spljoštenosti (KURT).

Daljnja statistička obrada podrazumijevala je višestruku regresijsku analizu s forward algoritmom selekcije varijabli u model pri čemu je za kriterijsku varijablu uzeta procjena ostvarenosti ciljeva i zadaća nastave (POTK), a za prediktorske varijable uzete su varijable: staž u nastavi (SUN), staž u izvannastavnim aktivnostima (SIN), ocjena suradnje s privrednim subjektima (OSPS), ocjena suradnje s roditeljima (OSR), ocjena opremljenosti alatima i strojevima (OOAS), ocjena opremljenosti instrumentima (OOI), ocjena opremljenosti računalima, sučeljima i softverom (OORS) i ocjena opremljenosti i stanja nastavnih sredstava (OONS). Izračunati su koeficijent multiple korelacije, koeficijent multiple determinacije, parametri $b$ i beta i pridružene značajnosti. Svi rezultati obrađeni su na računalu uz pomoć statističkog programa Statistica 8.0.

\section{Rezultati istraživanja}

Deskriptivnom statistikom obrađene su sve varijable, uključivo i kriterijsku, ponajprije zbog realizacije sekundarnog cilja istraživanja, koji se odnosi na analizu pojedinih elemenata materijalno-tehničke osnovice nastave Tehničke kulture, ali i utvrđivanja strukture ispitanika. Ujedno su utvrđene karakteristike distribucija pojedinih varijabli radi izbora optimalne metodologije za utvrđivanje onih prediktora koji izravno mogu utjecati na nastavnikovu percepciju ostvarenosti ciljeva i zadaća nastave.

Tablica 1.

Iz vrijednosti deskriptivnih statističkih parametara odabranih prediktorskih varijabli (tablica 1.) jasno se uočava iskustvena struktura ispitanika i njihove ocjene pojedinih odabranih kontekstualnih elemenata nastave, kao i distribucija percepcije ostvarenosti ciljeva i zadaća nastave. Ispitanici, premda prosječno visokog radnog iskustva u nastavi ( $>16$ godina) i izvannastavnim aktivnostima ( $>10$ godina), $s$ obzirom na 
visoku disperziju rezultata (CV=69,40\%), zastupaju sve dobne i iskustvene skupine učitelja tehničke kulture. Taj je podatak od ključne važnosti s obzirom na to da on utječe na višu razinu reprezentativnosti rezultata istraživanja. Nadalje, kad je u pitanju ocjena suradnje škole $s$ odabranim vanjskim elementima, vidljiva je znatno viša ocjena takve suradnje s roditeljima $(2,46)$ od ocjene suradnje škole s privrednim subjektima (1,71). Uzevši u obzir prethodne skale procjene, prosječna ocjena suradnje škole s privrednim subjektima jest ispod zadovoljavajuće razine, a prosječna ocjena suradnje škole s roditeljima može se smatrati zadovoljavajućom. Iz tablice 1. vidljivo je da, kad je u pitanju ocjena opremljenosti pojedinim vrstama materijalno-tehničke osnovice nastave tehničke kulture, jedino je opremljenost računalima, sučeljima i softverom (OORS) ocijenjena iznad zadovoljavajuće razine $(2,41)$, a sve su ostale kategorije opremljenosti ocijenjene ispod te razine. Podaci iz tablice koji se odnose na asimetričnost distribucije pojedinih varijabli ukazuju na to da su jedino podaci o stažu nastavnika u izvannastavnim aktivnostima (SIN) asimetrično distribuirani $($ SKEW $=1,01)$. Iz podataka o spljoštenosti distribucije pojedinih prediktorskih varijabli također jedino varijabla staž nastavnika u izvannastavnim aktivnostima (SIN) ima približno nultu spljoštenost (KURT $=0,07)$, a ostale varijable imaju negativnu. Navedeno ukazuje na činjenicu kako između nastavnika postoje velike razlike u takvom iskustvu. Taj se podatak jasno vidi i iz koeficijenta varijacije koji je za tu varijablu uvjerljivo najviši (100,70\%). Pritom je potrebno istaknuti da najmanje variraju podaci o percepciji ostvarenosti ciljeva i zadaća nastave tehničke kulture (POTK) i ocjene suradnje škole s roditeljima (OSR), čiji koeficijenti varijacije iznose $18,99 \%$, odnosno $29,00 \%$. Kolmogorov-Smirnovljevim testom je kod nekoliko varijabli uočeno blago odstupanje od normalne distribucije. To je vjerojatno posljedica njegove osjetljivosti prema relativno velikim uzorcima, kao što je slučaj u ovom istraživanju.

Tablica 2.

Ipak, iz navedenih podataka deskriptivne statistike nije moguće utvrditi povezanost prediktorskih varijabli s nastavničkom percepcijom ostvarenosti ciljeva i zadaća nastave, zbog čega je opravdana upotreba višestruke regresijske analize kao metodološkog alata daljnje obrade podataka.

Provedenom višestrukom regresijskom analizom (tablica 2.) dobiven je model s tri prediktorske varijable koje najznačajnije određuju kriterijsku varijablu. To su varijable: ocjena opremljenosti alatima i strojevima (OOAS), ocjena suradnje škole s privrednim subjektima (OSPS) i ocjena opremljenosti i stanja nastavnih sredstava (OSNS).

Višestruka korelacija tih varijabli prema kriterijskoj varijabli (POTK) iznosi relativno malih $\mathrm{R}=0,28$. Beta koeficijent iz tablice 2. pokazuje kako varijabla ocjena opremljenosti alatima i strojevima (OOAS) najviše određuje kriterijsku varijablu $(\beta=0,20)$, na razini značajnosti $\mathrm{p}=0,00$. To je najvažniji nalaz $\mathrm{u}$ ovom istraživanju i ukazuje na to kako opremljenost i upotreba alata i strojeva u nastavi tehničke kulture može značajno utjecati, odnosno predvidjeti, nastavničku percepciju uspjeha 
te nastave. Uzimajući u obzir sva ograničenja valjanosti nastavnikove percepcije uspješnosti nastave, nedvojbeno proizlazi kako opremljenosti alatima i strojevima $u$ nastavi tehničke kulture može bitno utjecati na kakvoću te nastave u cjelini. S obzirom na primarnu namjenu alata i strojeva znakovito je kako nastavnici svoju percepciju ostvarenosti ciljeva i zadaća nastave tehničke kulture dobrim dijelom temelje na praktičnoj aktivnosti učenika u nastavi.

Varijable ocjena suradnje škole s privrednim subjektima (OOPS) i ocjena opremljenosti i stanja nastavnih sredstava (OONS) znatno manje određuju kriterijsku varijablu $(\beta=0,09 / 0,08)$ s razinom značajnosti $p>0,05$. Premda se, zbog tako male značajnosti, navedeni kontekstualni čimbenici ne mogu smatrati pravim prediktorima nastavnikove percepcije ostvarenosti ciljeva i zadaća nastave, njihovo pojavljivanje u ovom modelu ipak je indikativno. Suradnja škole s privrednim subjektima(OOPS), kao prediktor nastavnikove percepcije nastave, nije očekivana u ovom modelu, što je iznimno važno za istraživanje. Neovisno o malom utjecaju na kriterijsku varijablu, nalaz navedene varijable ukazuje na to kako se nastava tehničke kulture treba oslanjati i na širi kontekst s kojim uostalom, zbog svoje radno-socijalne i profesionalne funkcije (Milat, 1996), treba biti povezana. Utjecaj varijable opremljenosti i stanja nastavnih sredstava (OONS) na kriterijsku varijablu, pa time i udio te varijable u dobivenom modelu, jest očekivan, premda je neočekivano malen.

Izostanak ostalih mogućih prediktorskih varijabli iz tog modela značajan je utoliko jer jasno pokazuje kako mnogi kontekstualni čimbenici, koji su na prvi pogled važni za nastavnikovu percepciju nastave, zapravo značajno ne utječu na tu percepciju.

\section{Rasprava}

Izdvojeni model jasno ukazuje na to kako je, neovisno o niskom $\beta$ koeficijentu i povezanosti modela s kriterijskom varijablom $(\mathrm{R}=0,28)$, ocjena opremljenosti alatima i strojevima (OOAS) identificirana kao značajan prediktor na temelju kojeg se očituje važnost ovog istraživanja. Ta je značajnost utoliko važnija jer kontekstualni čimbenici nisu osnova za vrednovanje učinkovitosti nastavnog procesa ni nastavnika.

Zbog veličine uzorka, zatim raznolike dobne, obrazovne i urbane strukture nastavnika, ustanovljene tijekom istraživanja, kao i zbog njihove iskustvene zastupljenosti (tablica 1.), ocjene pojedinih kontekstualnih čimbenika mogu se smatrati realnim pokazateljem stvarnog stanja tih čimbenika u nastavi Tehničke kulture u Republici Hrvatskoj. Prema tim pokazateljima najlošije je ocijenjena opremljenost škola instrumentima $(1,54)$ potrebnim za izvođenje tehničkih pokusa, koji se u nastavi Tehničke kulture smatraju bitnom komponentom radne metode predviđene nastavnim planom i programom (Nastavni plan i program za osnovnu školu, 2006). Iznimno niskom ocjenom (1,71) ocijenjena je opremljenost škole alatima i strojevima i suradnja škole s privrednim subjektima. Slaba opremljenost alatima i strojevima zasigurno determinira realizaciju druge bitne komponente radne metode predviđene nastavnim planom i programom koja se odnosi na izradu jednostavnih 
tehničkih tvorevina. S obzirom na to da je ocjena stanja i razine opremljenosti nastavnim sredstvima na granici pozitivne ocjene $(1,90)$, upitna je provedba i treće komponente radne metode ključne za realizaciju programa koja se odnosi na rad na projektnim konstrukcijskim zadacima. Takve ocjene zasigurno nisu jamstvo uspješne realizacije plana i programa nastave Tehničke kulture, odnosno ostvarivanja ciljeva i zadaća te nastave. Ipak, manjkavost loše ocijenjenih čimbenika nipošto nije nešto na što se ne bi moglo uspješno djelovati radi učinkovitog poboljšanja tih uvjeta. Od svih ocjena kontekstualnih čimbenika pozitivno su ocijenjene samo opremljenost računalima, softverom i sučeljima $(2,41)$ i suradnje škole i roditelja $(2,46)$. Važno je istaknuti da je ocjena stanja računala i računalne opreme produkt dugogodišnjeg i permanentnog ulaganja zajednice i nadležnih institucija u informatizaciju školstva, no oprema sama po sebi očito nije povezana s nastavnikovom percepcijom ostvarenosti ciljeva i zadataka nastave Tehničke kulture, pa stoga, vrlo vjerojatno, ni s učinkovitošću nastave Tehničke kulture. Pozitivna ocjena suradnje roditelja i škole zasigurno će se pozitivno odraziti i na nastavu Tehničke kulture, no nije utvrđen značajniji utjecaj te ocjene na nastavnikovu percepciju ostvarenosti ciljeva i zadaća nastave.

Prema rezultatima višestruke regresijske analize (tablica 2.) vidljiva je struktura i značajnost utjecaja pojedinih kontekstualnih čimbenika na nastavnikovu percepciju ostvarenosti ciljeva i zadaća u nastavi Tehničke kulture. Premda vrijednost višestruke korelacije izdvojenog modela $(\mathrm{R}=0,28)$ nije velika, ipak se izdvojene prediktorske varijable mogu smatrati indikativnima za tu percepciju. $U$ tom kontekstu najznačajnija je varijabla ocjena opremljenosti alatima i strojevima čija značajnost na razini $\mathrm{p}=0.00$ snažno upućuje na to kako su alati i strojevi, kao jedan od najvažnijih materijalnih preduvjeta edukacije tehnike, bitan element nastavnikove percepcije učinkovitosti u nastavi Tehničke kulture. Iz modela je vidljiva i važnost ocjene suradnje škole $\mathrm{s}$ privrednim subjektima (OSPS) koja na granici značajnosti $(\mathrm{p}=0,07)$ sudjeluje $\mathrm{u}$ nastavnikovoj percepciji. Sve tri varijable uključene u regresijski model govore više o tome koje promatrane varijable nisu sastavnim dijelom tog modela nego o njihovu značenju. Pritom se može uočiti da nastavnikovu percepciju više određuje ocjena suradnje škole s privrednim subjektima od nekih, naoko važnijih, čimbenika kao što su ocjena suradnje roditelja i škole ili radno iskustvo nastavnika. Za posljednju varijablu modela, koja u njemu minorno sudjeluje $(\mathrm{p}=0,16)$, očekivana je povezanost $s$ nastavnikovom percepcijom s obzirom na to da su nastavna sredstva bitna komponenta materijalno-tehničke osnove nastave tehničke kulture. Ne iznenađuje činjenica što ocjena opremljenosti računalima, sučeljima i softverom nije povezana s nastavnikovom percepcijom. Takav je rezultat vjerojatno posljedica intenzivne prisutnosti računala i računalne opreme tijekom protekla dva desetljeća, ali i neprikladnosti takve opreme kao temeljne materijalne podloge u edukaciji tehnike. Dodatno, nepovezanost ocjene opremljenosti instrumentima s nastavnikovom percepcijom također nije iznenađujuća jer se, s obzirom na najnižu prosječnu ocjenu $(1,57)$, pokazuje krajnja zapuštenost tehničkog eksperimenta u nastavi Tehničke kulture, a time i utjecaj na nastavnikovu percepciju ostvarenosti ciljeva i zadaća te nastave. 
Iako istraživanje nedvojbeno ukazuje na važnost pojedinih kontekstualnih čimbenika u nastavi tehničke kulture, neophodno je sagledati i njegova moguća ograničenja. Osim moguće nastavnikove subjektivne procjene ostvarenosti ciljeva i zadaća nastave, koja može biti ograničavajući faktor ovog istraživanja, nedostatak podataka bitnih za kontekst nastave također može umanjiti rezultate istraživanja. Naime, cijeli niz kontekstualnih čimbenika kao što su: urbanost mjesta u kojem se nastava izvodi, životni standard obitelji učenika, gospodarska razvijenost područja, privredna struktura, školska uprava i administracija, kulturološka obilježja sredine također mogu utjecati na nastavu i na nastavnikovu percepciju postignuća u toj nastavi. $S$ obzirom na to da je na te čimbenike u stvarnoj organizaciji nastave teško izravno djelovati i da njihovo istraživanje predstavlja zahtjevan i dugotrajan proces, oni su izostavljeni iz istraživanja. Njihovo izostavljanje ipak predstavlja bitno ograničenje jer nije moguće jasno predvidjeti kako bi, u konačnici, oni mogli utjecati na nastavnikovu percepciju ostvarenosti ciljeva i zadaća nastave tehničke kulture.

\section{Zaključak}

Operacionalizacijom primarnog cilja istraživanja identificirani su i objašnjeni mjerljivi kontekstualni čimbenici za koje se pretpostavljalo da mogu utjecati na nastavnikovu percepciju razine ostvarenosti ciljeva i zadaća nastave Tehničke kulture. Istraživanje je, u kontekstu tog cilja, identificiralo važan kontekstualni čimbenik nastave Tehničke kulture bitan za ostvarivanje ciljeva i zadaća te nastave, a to je opremljenost alatima i strojevima za izvođenje te nastave. Istraživanje je ujedno pokazalo i stanje bitnih internih kontekstualnih čimbenika, odnosno materijalno tehničke osnovice nastave Tehničke kulture kao što su: alati i strojevi, instrumenti i nastavna sredstva. Kako je riječ o čimbenicima koji se, uz minimalnu angažiranost prikladnih resursa mogu poboljšati, izrazito niske ocjene tog stanja mogu se smatrati akutnim problemom nastave tehničke kulture.

Nadalje, rezultati istraživanja nastavnikove percepcije ostvarenosti ciljeva i zadaća nastave ukazuju na opravdanost mnogih iskustvenih pokazatelja koji upućuju na važnost konteksta za edukaciju tehnike. Provedeno istraživanje indikativno ukazuju na to da materijalno-tehničko okruženje u kojem se izvodi nastava Tehničke kulture značajno djeluje na nastavnikovu percepciju te nastave. Iz rezultata je uočljiva važnost internog (školskog) okruženja, ali je indikativna i važnost eksternog (tehničkoproizvodnog) okruženja za nastavnikovu percepciju.

Navedeni pokazatelji mogu značiti samo to kako je kao preduvjet visoke ocjene nastavnikove percepcije ostvarenosti ciljeva i zadaća nastave Tehničke kulture neophodna dobra materijalno-tehnička osnovica te nastave i kooperativno tehničkoproizvodno okruženje. Buduća istraživanja edukacije tehnike svakako bi trebala uzimati u obzir opremljenost alatima i strojevima, ali i odnos škole s tehničkoproizvodnim okruženjem kao bitnim prediktorima učinkovitosti takve edukacije. 